\title{
オオアジサシを瀨戸內海で探集
}

\section{A specimen record of Thalasseus bergii cristatus from the Inland Sea}

\author{
小林 桂 助
}

\section{Keisuke Kobayashi}

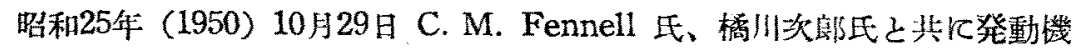

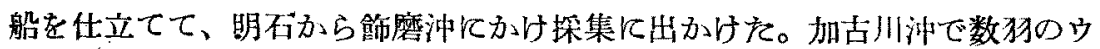
ミネコを見をので、その中一狗を採集したが、ウミネコが海上落下すると

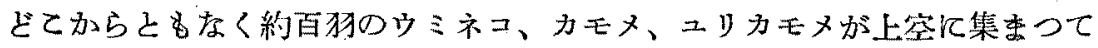
来を。注意深く観察するとその群に混つて只一旸大形のアジサシ科の鳥が后 ので採集した所オォアジサシの婎ですつた。ての日カモメ類の群を見る每に る注意深く観祭したが他には本種を一狗与見る事が出来索かつた。

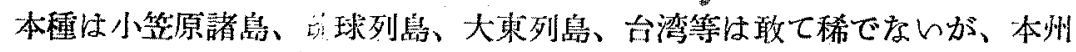

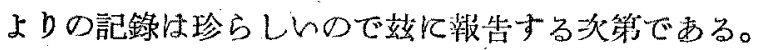

\section{Résumé}

In October 29, 1950, I collected off the mouth of the Kakogawa, Hyogo Prefecture at the Honshu side of the Inland Sea a male of Thalasseus bergii cristatus among a flock of Larus crassirostris.

This species of a Tern is not uncommonly found in the Bonins, Ryukyus and further south but is a rare straggier to the Japanese main islands. 